\title{
Short-term modulation of lipogenesis by macronutrients in rainbow trout (Oncorhynchus mykiss) hepatocytes
}

\author{
M. J. Alvarez ${ }^{1}$, A. Díez ${ }^{1}$, C. López-Bote ${ }^{2}$, M. Gallego ${ }^{1}$ and J. M. Bautista ${ }^{1 *}$ \\ ${ }^{1}$ Departamento de Bioquímica y Biología Molecular IV and ${ }^{2}$ Departamento de Producción Animal, Universidad \\ Complutense de Madrid, Facultad de Veterinaria, 28040 Madrid, Spain
}

(Received 5 July 1999 - Revised 24 January 2000 - Accepted 28 February 2000)

\begin{abstract}
Rainbow trout (Oncorhynchus mykiss) hepatocytes were cultured under simulated conditions of varying nutritional status to explore the short-term modulation by dietary substrates of the main lipogenic enzymes: glucose-6-phosphate dehydrogenase (G6PD), malic enzyme (ME), ATPcitrate lyase (ACL), acetyl-CoA carboxylase (ACoAC) and fatty acid synthetase (FAS). Primary cultures were individually exposed to varying amounts of glucose, hydrolysed casein and longchain polyunsaturated fatty acids (PUFA) for $12 \mathrm{~h}$. A second set of experiments was designed to evaluate the effects of mixing different relative amounts of these macronutrients in the culture medium. Glucose concentrations of up to $20-25 \mathrm{mM}$ showed a stimulatory effect on G6PD, ME, ACL and ACoAC activity $(P<0 \cdot 05)$ while an earlier inhibitory effect on FAS was observed at 10-20 mM glucose $(P<0 \cdot 05)$. The use of hydrolysed casein as a nutritional source of amino acids inhibited the activity of FAS and ME $(P<0 \cdot 05)$, and stimulated G6PD, ACoAC and ACL activity $(P<0.05)$. Low levels of linolenic acid exerted a stimulatory effect on all the lipogenic enzymes assayed $(P<0.05)$ with the exception of FAS, and increased amounts showed some inhibition of lipogenic activities $(P<0 \cdot 05)$. Eicosapentaenoic acid and docosahexaenoic acid showed a similar effect, although the former strongly inhibited FAS activity while the latter showed greater potential to inhibit ACoAC and G6PD. A complete change in the relative levels of glucose, hydrolysed casein and PUFA in turn led to changes in the enzyme activity patterns observed. The present study shows the feasibility of exploring the direct regulation of lipogenesis in isolated fish cells by varying the relative amounts of main macronutrients, mimicking in vivo dietary conditions. It is felt that such an approach may serve to investigate the macronutrient regulation of other metabolic pathways.
\end{abstract}

Lipogenesis: Hepatocytes: Rainbow trout

The regulation of enzyme activities by macronutrients is an important mechanism in the adaptation of animals to their nutritional environment, particularly when these are subjected to strict dietary control. Of special relevance in energy storage pathways, this type of control mechanism affects key enzymes involved in carbohydrate catabolism and lipogenesis in liver and adipose tissue (Foufelle et al. 1996).

The metabolic pathways of lipid biosynthesis and oxidation in fish are essentially the same as those observed in mammalian systems, although fatty acid requirements vary greatly among species and tissues and, in fish, have been related to the different fatty acid composition of different species (Henderson \& Tocher, 1987) as well as to the physiological life status (Sheridan, 1994). Long-term feeding and short-term radiolabelling studies have shown that most lipogenic activity in fish takes place in the liver. Indeed, salmon fatty acid synthesis was reported to be thirty times faster in the liver than in adipose tissue (Lin et al. 1977) although fish lipid metabolism is a dynamic process which may be conditioned by factors such as the availability of food, temperature and environmental changes (Bell et al. 1986; Sheridan, 1994). Nevertheless, as previously pointed out, knowledge of the regulation of fatty acid synthesis and lipogenic enzymes in fish is fragmentary and has been largely unexplored (Segner \& Böhm, 1994).

Over the last three decades, rodent liver cell primary cultures have proved to be of value for the investigation of

\footnotetext{
Abbreviations: ACL, ATP-citrate lyase; ACoAC, acetyl-CoA carboxylase; FAS, fatty acid synthetase; G6PD, glucose-6-phosphate dehydrogenase; ME, malic enzyme; PUFA, polyunsaturated fatty acids.

* Corresponding author: Dr José M. Bautista, fax + 3491 3943824, email bauchem@eucmax.sim.ucm.es
} 
hepatic metabolism, gene expression and regulation, hepatotoxicity, cell growth and carcinogenesis. The use of isolated hepatocytes has been recently expanded but has rarely been applied to non-mammalian systems (Moon et al. 1985), although relevant studies have already been modelled on teleost hepatocyte cultures (for review see Segner, 1998). The study of the regulation of lipogenesis in fish by dietary factors has been commonly approached by the analysis of the metabolic status of fish subjected either to long-term feeding on well-defined diets (Shimeno et al. 1995; Dias et al. 1998) or to prolonged exposure of cultured cells to mammalian hormones and metabolic effectors (Tocher et al. 1989; Segner et al. 1994; Segner, 1998).

In contrast, scarce attention has been paid to the shortterm regulation of lipogenesis in primary cultures of teleost hepatocytes by main dietary substrates (carbohydrates, proteins and fat) independently of hormonal stimuli. The aim of the present study was to explore the use of hepatocyte primary cultures to investigate the short-term basal induction of lipogenic flux in rainbow trout (Oncorhynchus mykiss), and to examine the direct effects of main nutritional substrates on the activities of glucose-6phosphate dehydrogenase (G6PD), malic enzyme (ME), ATP-citrate lyase (ACL), acetyl-CoA carboxylase $(\mathrm{ACoAC})$ and fatty acid synthetase (FAS).

\section{Material and methods}

\section{Animals}

Rainbow trout weighing 200-300 g were obtained from Industrias Piscícolas Españolas Agrupadas, Fuentidueña, Segovia, Spain. The fish were kept in aquaria at $15^{\circ} \mathrm{C}$ and were fed commercial feed. Prior to liver perfusion, the animals were subjected to a $36 \mathrm{~h}$ fast, which produced a basal glycaemia of $5 \mathrm{~mm}$.

\section{Isolation of liver cells and culture media}

Cells were isolated by in situ perfusion of the liver with $55 \mathrm{~g}$ collagenase/l as previously described and modified for trout (Klauning, 1984; Klauning et al. 1985), and resuspended in Leibovitz L-15 medium pH 7.4 (Leibovitz, 1963) supplemented with $100 \mathrm{ml}$ fetal calf serum/l, $10 \mathrm{ml}$ trout serum/l, $500 \mu \mathrm{g}$ insulin/l and $5.5 \mathrm{mM}$-glucose. The resultant suspension was plated to a density of $6.6 \times 10^{5}$ cells/ml in Corning ${ }^{\mathrm{TM}}$ plastic dishes (Corning, New York, NY, USA) coated with type IV collagen. The cultures were maintained at $17 \pm 1^{\circ} \mathrm{C}$ in a refrigerated chamber.

Mammalian serum is known to contain relatively low levels of long-chain polyunsaturated fatty acids (PUFA) and to induce essential fatty acid deficiency in fish cell cultures (Spector et al. 1981). This effect may be partially reduced by supplementation with trout serum in culture (Tocher et al. 1988). The survival of trout hepatocyte monolayers supplemented in this manner was from 5 to 6 weeks. Hepatocyte survival in the absence of serum was greatly diminished (under 2 weeks). Moreover, in preliminary experiments, highly reproducible results were obtained under these conditions while, in the absence of serum, these were extremely variable, probably due to heterogeneous cell stability.

Cell viability was assessed by the Trypan Blue exclusion method (4 g/l PBS). The total number of cells and percentage of viable cells was calculated for each liver isolate and cell suspension. The medium was replaced $7 \mathrm{~h}$ after plating, and every $24 \mathrm{~h}$ until confluent monolayers were obtained. The relevant substrates were added to the basal medium at the time of culture medium replacement. The different concentrations of glucose, hydrolysed casein and free fatty acids of different lengths required to maintain $100 \%$ cell viability were established in preliminary trials.

Linolenic, eicosapentaenoic and docosahexanoic acids were bound to fatty acid-free bovine serum albumin as described by Chen (1967). Cultures treated with the corresponding amount of unbound, fatty acid-free bovine serum albumin solution served as controls.

Test media were prepared using a mixture of the three main substrates found in common fish meal (carbohydrate, protein and fat). The quantitative compositions of the different culture media are provided in Table 1. Control culture media contained basal levels of the nutrients (Leibovitz L-15 medium pH 7.4 (Leibovitz, 1963) containing $100 \mathrm{ml}$ fetal calf serum/l, $10 \mathrm{ml}$ trout serum/l, $500 \mu \mathrm{g}$ insulin/l and $5.5 \mathrm{mM}$-glucose).

To investigate the short-term induction of the lipogenic enzymes in the isolated hepatocytes, each culture was exposed to the experimental medium for $12 \mathrm{~h}$. In agreement with the findings of other authors (Geelen, 1994; Segner et al. 1994), preliminary time-course experiments using media containing different amounts of glucose, casein and fatty acids (data not shown) indicated that a stable effect of the nutritional substrate was produced after $12 \mathrm{~h}$ incubation. Microscopic examination of the hepatocyte cultures ensured the absence of morphological alterations under the experimental conditions described.

\section{Enzyme assays}

After exposure to the experimental media, the cultures were washed in PBS and cells harvested using a cell scraper. Once resuspended in three volumes of ice-cold buffer $(0 \cdot 2 \mathrm{M}$-Tris-HCl, $0 \cdot 5 \mathrm{M}$-sucrose, $2 \mathrm{mM}$-EDTA, $0 \cdot 1 \mathrm{M}-\mathrm{NaF}$, $0.5 \mathrm{mM}$-phenylmethylsulfonyl fluoride, 0.01 M-mercaptoethanol, $\mathrm{pH} 7.4$ ), they were homogenised by sonication. The cell suspension was centrifuged at $140000 \mathrm{~g}$ at $4^{\circ} \mathrm{C}$ for $40 \mathrm{~min}$. The supernatant obtained was used as the cell extract for the determination of the selected lipogenic enzyme activities using spectrophotometric procedures for G6PD (Bautista et al. 1988), ME (Ochoa, 1955) and ACL (Srere, 1962), and isotopic methods for ACoAC (Holland et al. 1984) and FAS (Hsu et al. 1969). All the enzyme activity assays were conducted at $30^{\circ} \mathrm{C}$. Care was taken to ensure that initial rates were being measured in all assays. Control experiments established that the enzyme was stable in the buffer used during the time of measurement, and at the temperature required to perform the assay (Alvarez et al. 1998).

The enzyme assays were performed in duplicate on samples from three independent cell cultures. One unit of enzyme activity (IU), defined as $\mu \mathrm{mol}$ substrate converted 
Table 1. Design and quantitative composition of the experimental media used to analyse the combined effects of modifying the relative amounts of glucose, protein and fat on lipogenesis in rainbow trout hepatocytes

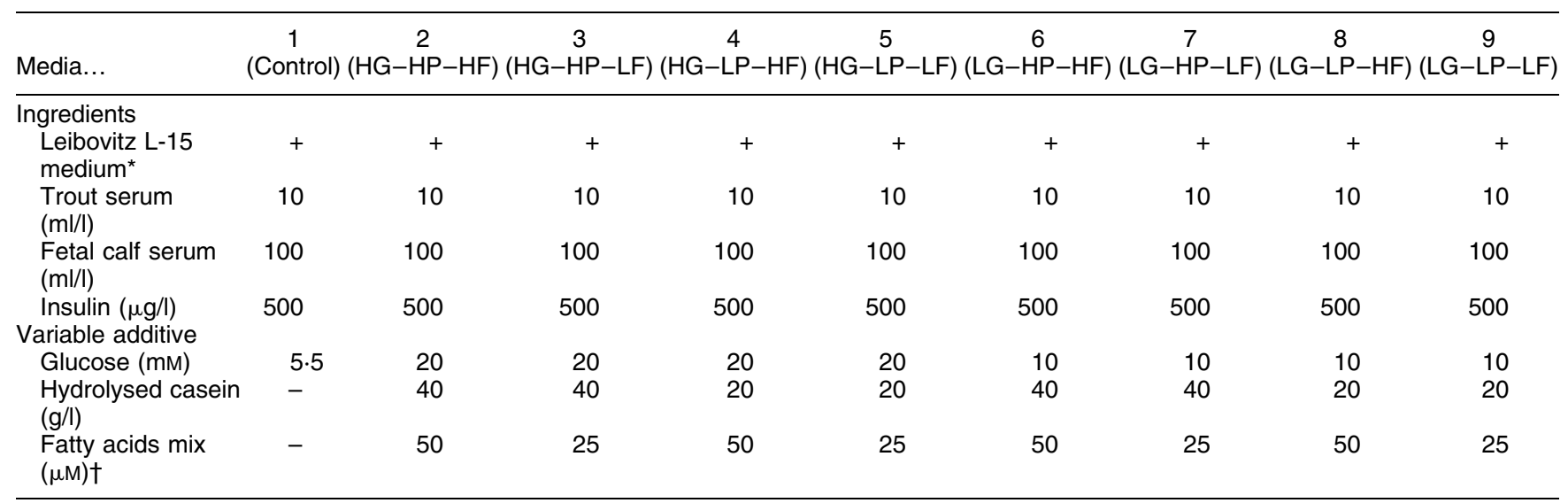

$H$, high; $G$, glucose; $P$, protein; $F$, fat; L, low.

* Leibovitz, 1963.

† Fatty acids were bound as albumin complexes. The concentration refers to the total fatty acid level of an equimolar mixture of $18: 3 n-3+20: 5 n-3+22: 6 n-3$.

to product per min at $30^{\circ} \mathrm{C}$, was expressed per $\mathrm{mg}$ of hepatic soluble protein (specific activity).

Protein was determined by the Bio-Rad ${ }^{\mathrm{TM}}$ dye method reagent (Bio-Rad, Hercules, CA, USA) using bovine serum albumin as the standard.

\section{Reagents}

Collagenase, type IV collagen, Trypan Blue, glucose, hydrolysed casein, bovine serum albumin, insulin, dexamethasone, free fatty acids, acetyl coenzyme A, malonyl coenzyme A, malate dehydrogenase and the reagents for the cell culture media were supplied by Sigma (St Louis, MO, USA). $\left[{ }^{14} \mathrm{C}\right]$ acetyl coenzyme A $(2035 \mathrm{MBq} / \mathrm{mmol})$ and $\left[{ }^{14} \mathrm{C}\right]$ sodium bicarbonate $(259 \mathrm{MBq} / \mathrm{mmol})$ were obtained from Dupont NEN ${ }^{\circledR}$ Research Products (Drereich, Germany). Fetal calf serum was purchased from Sera-Lab (Crawley Down, Sussex, UK).

\section{Statistical methods}

Response data were evaluated by the General Linear Model procedure (SAS User's Guide: Statistics, 1998; Statistical Analysis Systems Institute Inc., Cary, NC, USA). An individual culture was the experimental unit for analysis of all data ( $n$ 3). Data were analysed as a completely randomised design. Differences between treatment means within the analysis of variance were determined by Duncan's multiple range test. To investigate the effects of different relative amounts of carbohydrate, protein and fat on short-term modulation of lipogenic activities (Table 1), the comparative analyses between means were carried out using orthogonal contrasts. Data were presented as the means of each group and pooled standard deviation together with the significance levels of the main effects and interactions. In all cases, statistical analyses were accomplished using software procedures contained in SAS (version 6.04, Statistical Analysis Systems Institute Inc.).

\section{Results}

\section{Glucose-regulated lipogenic activities}

After the initial hepatocyte isolation procedure, it was observed that to maintain cell viability for more than a few days, $5.5 \mathrm{mM}$-glucose was required in the culture medium. The enzyme activities determined at this glucose concentration were always lower than those observed in hepatocytes incubated in the presence of higher glucose concentrations and were thus taken as the basal enzyme activities of the system. In vivo, the level of glycaemia of starved rainbow trout is homeostatically maintained within the range 4.4 to $6.0 \mathrm{mM}$ (Bergot, 1979; Brauge et al. 1994). Nevertheless, after feeding, trout blood glucose concentration has been reported to rise to up to $17 \mathrm{mM}$ and, unlike in mammals, this physiologically-induced high glycaemia is maintained for long periods (Brauge et al. 1994).

Based on this starting value $(5.5 \mathrm{~mm})$, several glucose concentrations were tested as a nutritional source of carbohydrates with the aim of assessing directly the effects of metabolic energy changes on lipogenic activities.

As the glucose concentration was increased from the basal $5.5 \mathrm{mM}$ to $25 \mathrm{mM}(P<0.05)$, G6PD was stimulated to a maximum 10 -fold increase in activity $(P<0.05)$, with as much as a 6-fold increase from 5.5 to $10 \mathrm{~mm}$ glucose. A dramatic inhibition of G6PD activity was produced at $30 \mathrm{~mm}$-glucose with a return to near basal values $(P<$ 0.05) (Fig. 1).

Similarly, ME activity (which like G6PD provides NADPH for fatty acid synthesis) showed a 14-fold induction at $20 \mathrm{~mm}$ glucose $(P<0 \cdot 05)$, but an earlier decay in its activity to basal values at 25 and $30 \mathrm{~mm}$ glucose $(P<0.05)$ (Fig. 1). ACL activity, although undetectable in hepatocytes incubated at the lowest glucose concentration $(5.5 \mathrm{mM})$, showed a high capacity of induction when the cells were incubated in the presence of $10-25 \mathrm{~mm}$-glucose $(P<0 \cdot 05)$. At $30 \mathrm{mM}$-glucose, ACL activity no longer increased, although maximum activity was maintained (Fig. 1).

A similar tendency was also observed in ACoAC 

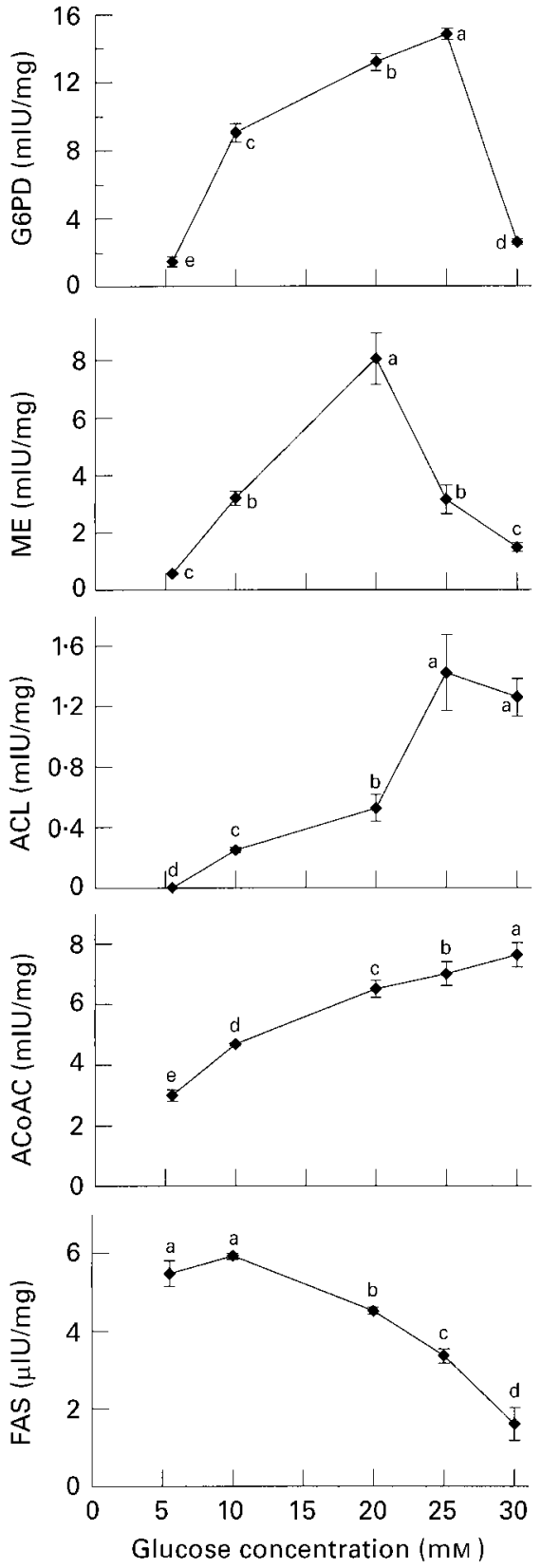

Fig. 1. The effect of increasing glucose concentrations on lipogenic enzyme activities in primary cultures of trout hepatocytes. The cells were incubated with the amounts indicated $12 \mathrm{~h}$ before assaying enzyme activity. For details of procedures see p. 620. G6PD, glucose-6-phosphate dehydrogenase; ME, malic enzyme; ACL, ATP-citrate lyase; ACoAC, acetyl-CoA carboxylase; FAS, fatty acid synthetase. Values are means for duplicate determinations performed on three individual cultures with standard deviations shown by vertical bars. ${ }^{a, b, c, d, e}$ Mean values with unlike superscript letters were significantly different $(P<0.05)$.

activity, which showed progressive increase as the glucose concentration rose in the culture medium. The activity of this enzyme was detectable at the lowest glucose level and continuously increased even from 25 to $30 \mathrm{~mm}$-glucose $(P<0 \cdot 05)$. However, only a 2.5 -fold difference was observed between minimum and maximum activities (at
5.5 and $30 \mathrm{mM}$-glucose respectively) reflecting the lowest induction potential of the five enzymes under study (Fig. 1).

Although the G6PD, ME, ACL and ACoAC enzyme activities showed similar patterns of induction as a function of increased glucose concentrations from 5.5 to $20-25 \mathrm{mM}$, FAS activity showed negligible capacity for induction. From 5.5 to $10 \mathrm{mM}$-glucose, FAS showed maximum activity, only to show marked inhibition from 10 to $30 \mathrm{~mm}$-glucose leading to values below basal $(P<0.05)$.

\section{Hydrolysed casein as a nutritional source of protein}

To assess the metabolic capacity of a nutritional source of protein to directly modulate lipogenesis, the trout hepatocytes were cultured in basal medium (see p. 620) in the absence and presence of 20 and $40 \mathrm{~g}$ hydrolysed casein/l. Bovine casein is a source of protein with a balanced composition of amino acids, which is employed as a supplement in fish (Gongnet et al. 1996) and mammalian diets (Officer et al. 1997).

The presence of 20 or $40 \mathrm{~g}$ hydrolysed casein/l in the medium produced a 3 -fold inhibitory effect on FAS activity $(P<0.05)$. The activity of ME was also inhibited and a third of the original activity was recorded after treatment with $40 \mathrm{~g}$ casein/l $(P<0.05)$. In contrast, the presence of hydrolysed casein stimulated G6PD, ACoAC and ACL activities $(P<0.05)$, although the latter enzyme was inhibited at the higher protein concentration $(P<0.05)$ (Table 2).

Thus, hydrolysed casein served as a nutritional supply of amino acids and appeared to modulate metabolic flow in the hepatocytes.

\section{Influence of polyunsaturated free-fatty acids on hepatocyte lipogenesis}

The only lipids present in the basal culture medium were those supplied by the serum which was of $90 \%$ mammalian and $10 \%$ fish origin (see p. 620). The lipid fraction of this supplemented serum has been estimated to be less than $0.7 \mathrm{~g} / \mathrm{l}$ (Leger et al. 1981). Linolenic, eicosapentaenoic and docosahexaenoic acids were chosen as the nutritional source of $n-3$ PUFA and were tested at two levels, $(25$ and $50 \mu \mathrm{M})$ to investigate the lipogenic effects of free fatty acids on the hepatocytes. These fatty acids and their concentrations were selected on the grounds of the absence of cytotoxic effects (Geelen, 1994) and the fact that fish tissues are characterised by high levels of PUFA, predominantly of the $n-3$ series, essential for fish metabolism (Bell et al. 1986; Henderson \& Tocher, 1987). Control primary cultures of hepatocytes with no added fatty acids were supplemented with an equivalent amount of free bovine serum albumin (see p. 620).

The effects of the presence of different free fatty acids in the basal culture medium on the lipogenic enzyme activities are shown in Table 3. The inclusion of linolenic acid $(18: 3 n-3)$ at the lowest concentration $(25 \mu \mathrm{M})$ produced a stimulatory effect on all the enzymes with the exception of a slight inhibition of FAS activity $(P<0.05)$. This induction ranged from 2-fold for G6PD, ACL and $\mathrm{ACoAC}$ to 4 -fold for ME. The addition of $50 \mu \mathrm{M}$-linolenic 
Table 2. The effect of casein as a protein source on lipogenic enzyme activities in primary cultures of rainbow trout hepatocytes. The hepatocyte cultures were prepared using $36 \mathrm{~h}$ fasted trout and maintained in a medium containing $5.5 \mathrm{~mm}$-glucose

(Mean values for duplicate determinations on three cultures)

\begin{tabular}{|c|c|c|c|c|c|}
\hline Additive & $\begin{array}{c}\text { G6PD } \\
\text { (mlU/mg protein) }\end{array}$ & $\begin{array}{c}\text { ME } \\
\text { (mIU/mg protein) }\end{array}$ & $\begin{array}{c}\mathrm{ACL} \\
\text { (mIU/mg protein) }\end{array}$ & $\begin{array}{c}\text { ACoAC } \\
\text { (mIU/mg protein) }\end{array}$ & $\begin{array}{c}\text { FAS } \\
(\mu \mathrm{lU} / \mathrm{mg} \text { protein })\end{array}$ \\
\hline $\begin{array}{l}\text { None } \\
\text { Hydrolysed casein }\end{array}$ & $1 \cdot 20^{C}$ & $0.32^{a}$ & $0.08^{c}$ & $1.90^{b}$ & $4 \cdot 82^{a}$ \\
\hline $20 \mathrm{~g} / \mathrm{l}$ & $1.75^{\mathrm{b}}$ & $0.29^{a}$ & $2 \cdot 13^{a}$ & $2 \cdot 10^{\mathrm{b}}$ & $1 \cdot 62^{b}$ \\
\hline $40 \mathrm{~g} / \mathrm{l}$ & $4.03^{\mathrm{a}}$ & $0.12^{b}$ & $1 \cdot 20^{\mathrm{b}}$ & $2 \cdot 91^{\mathrm{a}}$ & $1.73^{b}$ \\
\hline Pooled SD & 0.251 & 0.049 & 0.156 & 0.274 & $0 \cdot 251$ \\
\hline$P>F$ & 0.0001 & 0.01 & 0.0001 & 0.01 & 0.0001 \\
\hline
\end{tabular}

G6PD, glucose-6-phosphate dehydrogenase; ME, malic enzyme; ACL, ATP-citrate lyase; ACoAC, acetyl-CoA carboxylase; FAS, fatty acid synthetase.

${ }_{\mathrm{a}, \mathrm{b}, \mathrm{c}}$ Mean values within a column with unlike superscript letters were significantly different $\left({ }^{\star} P<0.05\right)$.

acid (18:3n-3) led to the inhibition of some of the enzymes: G6PD and ACoAC activities fell to basal levels and FAS was further inhibited by a factor of 3.5 with regard to basal activity $(P<0.05)$. This high concentration of linolenic acid also led to 4 - and 7-fold increases in the activities of ACL and ME respectively with regard to basal levels $(P<$ 0.05).

Eicosapentaenoic acid (20:5n-3) and docosahexaenoic acid (22:6n-3) showed similar effects on lipogenic activity. At the lower levels $(25 \mu \mathrm{M})$, they provoked increased G6PD and ME activities $(P<0.05)$ and notably inhibited FAS activity $(P<0 \cdot 05)$. Low eicosapentaenoic acid concentration had no effect in ACL and ACoAC. The induction of G6PD activity by these fatty acids was attenuated, compared with the effects of linolenic acid. However, ACL activity showed a 5-fold increase when docosahexaenoic acid was added to the culture medium $(P<0.05)$. At the higher level $(50 \mu \mathrm{M})$, the effects of these fatty acids were similar to those of linolenic acid, i.e. inhibited G6PD, FAS and ACoAC activity and some induction of ME and ACL activity (only in the case of docosahexaenoic acid on this last enzyme).

The overall inhibitory effects shown by these fatty acids on the lipogenesis pathway were a strong inhibition of FAS activity by eicosapentaenoic acid and the greatest inhibitory potential shown by docosahexaenoic acid on ACoAC and G6PD. Thus, it would seem that the length of the fatty acid chain and the degree of saturation affects the modulation of lipogenic enzyme activities in the trout hepatocytes.

\section{Relative amounts of nutritional energy, protein and fat}

Based on the metabolic effects observed when each supplement was added to the culture medium, a model system was designed to investigate the effects of different relative amounts of carbohydrate, protein and fat on the short-term modulation of lipogenic activities. Table 1 shows the differential composition of the media employed.

The activities of the lipogenic enzymes in the hepatocytes exposed to the different media are shown in Table 4. Significant changes in general lipogenic activities were recorded depending on the relative amounts of glucose, protein and fat present.

The activity of G6PD was enhanced by increasing glucose and hydrolysed casein concentration $(P<0 \cdot 0001)$ and reduced by increasing fatty acid concentration $(P<$ 0.0001). An interaction effect of protein and fat was also observed in which activation of G6PD by protein was higher at the higher fatty acid concentrations $(P<0 \cdot 0001)$. Consequently, inhibition of G6PD activity by increased amounts of fatty acids was particularly marked at the lowest hydrolysed casein concentration. Maximum G6PD activity was recorded under conditions of high glucosehigh protein-low fat, and accordingly this enzyme showed

Table 3. The effects of three different polyunsaturated fatty acids on lipogenic enzyme activities in primary cultures of trout hepatocytes. The cells were incubated with the amounts indicated for $12 \mathrm{~h}$ before assaying enzyme activity

(Mean values for duplicate determinations on three cultures)

\begin{tabular}{|c|c|c|c|c|c|}
\hline Additive & $\begin{array}{c}\text { G6PD } \\
\text { (mIU/mg protein) }\end{array}$ & $\begin{array}{c}\text { ME } \\
\text { (mIU/mg protein) }\end{array}$ & $\begin{array}{c}\mathrm{ACL} \\
\text { (mIU/mg protein) }\end{array}$ & $\begin{array}{c}\text { ACoAC } \\
\text { (mlU/mg protein) }\end{array}$ & $\begin{array}{c}\text { FAS } \\
(\mu \mathrm{lU} / \mathrm{mg} \text { protein })\end{array}$ \\
\hline None & $1 \cdot 17^{d}$ & $0.21^{d}$ & $0 \cdot 15^{d}$ & $1.41^{a}$ & $3.51^{a}$ \\
\hline \multicolumn{6}{|l|}{ Linolenic acid } \\
\hline $25 \mu \mathrm{M}$ & $2 \cdot 33^{a}$ & $1.02^{b c}$ & $0.38^{\mathrm{C}}$ & $3 \cdot 01^{\mathrm{b}}$ & $2 \cdot 17^{\mathrm{b}}$ \\
\hline $50 \mu \mathrm{M}$ & $1 \cdot 26^{\mathrm{cd}}$ & $1.47^{\mathrm{a}}$ & $0.63^{\mathrm{b}}$ & $0.99^{\mathrm{C}}$ & $1.00^{\mathrm{C}}$ \\
\hline \multicolumn{6}{|c|}{ Eicosapentaenoic acid } \\
\hline $25 \mu \mathrm{M}$ & $1.42^{b}$ & $0.80^{c}$ & $0 \cdot 18^{d}$ & $1 \cdot 21^{\mathrm{c}}$ & $0.68^{c}$ \\
\hline $50 \mu \mathrm{M}$ & $1.01^{\mathrm{e}}$ & $0 \cdot 26^{d}$ & $0 \cdot 10^{d}$ & $0.67^{d}$ & $0 \cdot 10^{d}$ \\
\hline \multicolumn{6}{|c|}{ Docosahexaenoic acid } \\
\hline $25 \mu \mathrm{M}$ & $1 \cdot 37^{\mathrm{bc}}$ & $1 \cdot 10^{b}$ & $0.78^{a}$ & $1 \cdot 00^{c}$ & $0.82^{c}$ \\
\hline $50 \mu \mathrm{M}$ & $0.87^{f}$ & $0.77^{\mathrm{c}}$ & $0.65^{\mathrm{ab}}$ & $0.23^{c}$ & $0.65^{c}$ \\
\hline Pooled SD & 0.0748 & 0.160 & 0.160 & 0.240 & 0.272 \\
\hline$P>F$ & 0.0001 & 0.0001 & 0.0001 & 0.0001 & \\
\hline
\end{tabular}

G6PD, glucose-6-phosphate dehydrogenase; ME, malic enzyme; ACL, ATP-citrate lyase; ACoAC, acetyl-CoA carboxylase; FAS, fatty acid synthetase. $\mathrm{a}, \mathrm{b}, \mathrm{c}, \mathrm{d}, \mathrm{e}, \mathrm{f}$ Mean values within a column with unlike superscript letters were significantly different $\left({ }^{\star} P<0.05\right)$. 
Table 4. The effects of changes in glucose, protein and fat ratios on lipogenic enzyme activities in primary cultures of trout hepatocytes. The cells were incubated with the amounts indicated for $12 \mathrm{~h}$ before assaying enzyme activity

(Mean values for duplicate determinations on three cultures)

\begin{tabular}{|c|c|c|c|c|c|}
\hline Media & $\begin{array}{c}\text { G6PD } \\
\text { (mlU/mg protein) }\end{array}$ & $\begin{array}{c}\text { ME } \\
\text { (mIU/mg protein) }\end{array}$ & $\begin{array}{c}\mathrm{ACL} \\
\text { (mIU/mg protein) }\end{array}$ & $\begin{array}{c}\text { ACoAC } \\
\text { (mIU/mg protein) }\end{array}$ & $\begin{array}{c}\text { FAS } \\
\text { ( } \mu \mathrm{IU} / \mathrm{mg} \text { protein) }\end{array}$ \\
\hline 1 (Control) & $1 \cdot 28$ & 0.36 & 0.08 & $2 \cdot 10$ & 4.60 \\
\hline 2 (HG-HP-HF) & 29.03 & 3.40 & 1.91 & 1.73 & $2 \cdot 40$ \\
\hline 3 (HG-HP-LF) & 32.25 & $6 \cdot 86$ & 1.83 & 4.88 & $6 \cdot 00$ \\
\hline 4 (HG-LP-HF) & 17.80 & 1.98 & 1.13 & $3 \cdot 27$ & $2 \cdot 89$ \\
\hline 5 (HG-LP-LF) & 27.05 & 4.68 & $2 \cdot 25$ & $6 \cdot 13$ & 4.60 \\
\hline 6 (LG-HP-HF) & $20 \cdot 25$ & $2 \cdot 23$ & $2 \cdot 71$ & $1 \cdot 84$ & $2 \cdot 10$ \\
\hline 7 (LG-HP-LF) & $26 \cdot 40$ & 4.66 & $1 \cdot 84$ & 3.57 & 3.90 \\
\hline 8 (LG-LP-HF) & $10 \cdot 25$ & $5 \cdot 16$ & $2 \cdot 04$ & 1.48 & $2 \cdot 40$ \\
\hline 9 (LG-LP-LF) & $20 \cdot 30$ & $6 \cdot 22$ & 1.87 & $2 \cdot 46$ & $3 \cdot 21$ \\
\hline Pooled SD & 1.541 & 0.323 & 0.229 & 0.527 & 0.459 \\
\hline \multicolumn{6}{|c|}{ Probability of contrasts } \\
\hline Control v. others & 0.0001 & 0.0001 & 0.0001 & 0.01 & 0.001 \\
\hline HG $v . \mathrm{LG}$ & 0.0001 & 0.05 & 0.01 & 0.0001 & 0.0001 \\
\hline HP v. LP & 0.0001 & NS & 0.05 & NS & NS \\
\hline HF v. LF & 0.0001 & 0.0001 & NS & 0.0001 & 0.0001 \\
\hline Int $\mathrm{G} \times \mathrm{P}$ & NS & 0.0001 & NS & 0.0001 & NS \\
\hline Int $\mathrm{G} \times \mathrm{F}$ & NS & 0.0001 & 0.0001 & 0.01 & 0.01 \\
\hline Int $P \times F$ & 0.0001 & 0.001 & 0.0001 & NS & 0.01 \\
\hline Int $\mathrm{G} \times \mathrm{P} \times \mathrm{F}$ & NS & NS & NS & NS & NS \\
\hline
\end{tabular}

G6PD, glucose-6-phosphate dehydrogenase; ME, malic enzyme; ACL, ATP-citrate lyase; ACoAC, acetyl-CoA carboxylase; FAS, fatty acid synthetase; H, high; G, glucose; P, protein; F, fat; L, low; Int, interaction.

minimum activity in the presence of low glucose-low protein-high fat levels.

ME activity was reduced by high glucose $(P<0 \cdot 05)$ and fatty acid $(P<0.0001)$ concentration. An interaction effect of protein and glucose concentration was also observed $(P<0.0001)$ in which ME activity was enhanced by a high hydrolysed casein level in the high-glucose medium and inhibited by a similar level of casein in the low-glucose medium. Thus, inhibition or stimulation by high protein was dependent on the amount of glucose available. As observed for G6PD, ME activity was inhibited at high fatty acid concentrations but the degree of inhibition showed interaction with glucose and protein levels $(P<0.0001$ and $P<0.001$ respectively). Maximum ME activity was observed at high glucose-high protein-low fat levels. However, unlike G6PD activity, minimum ME activity was recorded under conditions of high glucose-low proteinhigh fat.

ACL activity was reduced by high-glucose $(P<0.01)$ and enhanced by high-protein $(P<0.05)$ concentration, but no effect of fatty acid concentration was observed. ACL showed the most discrete changes in activity in response to the varying proportions of nutrients. An interaction effect of protein and fat concentration was observed for ACL activity, in which protein enhanced activity only in high-fat groups $(P<0 \cdot 0001)$. An interaction effect of glucose and fat concentration was also observed, in which high glucose reduced ACL activity only in the presence of high fatty acid concentration $(P<0.0001)$.

ACoAC activity was enhanced by glucose $(P<0.0001)$ and reduced by fat $(P<0 \cdot 0001)$. No effect of protein concentration was observed on ACoAC, but an interaction effect of protein and glucose was observed $(P<$ 0.0001), in which at high glucose levels, ACoAC activity was inhibited by high casein irrespective of the fatty acid concentration, while at low-glucose concentration casein had limited effect. Maximum ACoAC activity was obtained at high glucose-low protein-low fat concentrations, although minimum activity was shown under three different high fat conditions: low glucose-low protein, high glucosehigh protein and low glucose-high protein.

The activity of FAS was enhanced by glucose concentration $(P<0 \cdot 0001)$ and reduced by fatty acid concentration $(P<0.0001)$. Moreover, an interaction effect of protein and fat was observed in which FAS activity was enhanced by protein concentration only at the lower fatty acid levels $(P<0 \cdot 01)$. An interaction effect of glucose and fat was also observed in which high glucose enhanced FAS activity only when fatty acid concentration was low $(P<$ $0 \cdot 01)$. Consequently, the presence of $50 \mu \mathrm{M}$ fatty acids in the medium led to basal activity regardless of the amount of glucose and/or casein. It would seem, therefore, that the level of fatty acids acts as the main nutritional regulator of FAS activity and that glucose and casein are able to modulate the enzyme at low fatty acid levels. Accordingly, maximum FAS activity was recorded at high glucose-high protein-low fat levels and minimum activity at high fatty acid levels regardless of the proportions of the remaining nutrients.

\section{Discussion}

The hepatocyte primary culture model provides an intact cellular ground for the short- and long-term investigation of biochemical functions comparable with those of in vivo liver cells (Gandemer et al. 1983; Bols \& Lee, 1991).

In mammalian cells, the lipogenic pathways involving different nutritional substrates and their regulatory mechanisms have been relatively well-defined (Wilson et al. 1990). However, in poikilotherms and particularly in fish, these nutritional lipogenic control mechanisms 
have yet to be established since they are commonly assumed to be similar to those operating in eutherms and due to the high variety of fish species. In addition, the particular physiological processes in the life history of poikilotherms (smoltification, metamorphosis, hibernation) reflect different requirements for lipid storage and utilisation (Sheridan, 1994).

Fish cell culture models have been recently employed for the evaluation of a variety of metabolic responses to different chemically defined media in the study of sugar utilisation (Harmon \& Sheridan, 1992a; Pereira et al. 1995), hormone action (Segner et al. 1994) and fatty acid catabolism (Tocher et al. 1989; Harmon \& Sheridan, $1992 b$ ). It has been shown that trout hepatocytes cultured in defined media maintain central metabolic pathways including lipogenesis, glycolysis and gluconeogenesis (Segner et al. 1994).

As a general rule, it has been established that glucose derived from the metabolism of dietary carbohydrate or glucogenic amino acids is the primary substrate for fatty acid synthesis in the liver (Newsholme \& Start, 1973). Moreover, the nutritional state and glucose concentration have been shown to be important modulators of lipid mobilisation in the isolated liver of rainbow trout (Harmon $\&$ Sheridan, 1992b). Further, the NADPH required for lipogenesis is also provided by the catabolism of glucose generated from any source including the $\mathrm{C}$ in glucogenic amino acids. In the present experimental model, this was shown by the enhanced lipogenic activity of the trout hepatocytes in the presence of 5-25 mM-glucose and $20 \mathrm{~g}$ and $40 \mathrm{~g}$ hydrolysed casein/l. These findings are in agreement with those of in vivo studies which report increased hepatic lipogenic enzyme activity, such as G6PD activity, in response to increased dietary carbohydrates in rainbow trout (Hilton \& Atkinson, 1982), sea bass (Dias et al. 1998), sturgeon (Fynn-Aikins et al. 1992), channel catfish (Likimani \& Wilson, 1982) and common carp (Shimeno et al. 1995). Thus, the incorporation of available glucose from the diet into hepatic lipogenic routes seems to be a common feature (Hung \& Storebakken, 1994) despite the general low carbohydrate level in natural or artificial fish diets (Wilson, 1994). It has been proposed, therefore, that liver lipogenesis may play a role in maintaining a constant glucose concentration in fish blood (Brauge et al. 1994; Shimeno et al. 1996) consistent with the relationship observed between the activity of fatty acid synthesising enzymes and glycogen levels in trout hepatocytes (Voss \& Jankowsky, 1986).

It is common practice to supplement the cell culture medium with a mixture of amino acids including those considered essential (Leibovitz, 1963). However, the relatively low amounts of amino acids in these systems ( $4 \mathrm{~g} / \mathrm{l})$ limits the use of these $\mathrm{C}$ skeletons for several metabolic purposes. The metabolic effect of protein as a macronutrient has recently been evaluated by isolating liver cells from animals previously fed different amounts of dietary protein (Ashida et al. 1998). As far as we are aware, no previous investigation explores the direct supplementation of cultured hepatocytes with an extra source of metabolic protein. Previous studies on amino acid metabolism in cultured cells including trout hepatocytes
(French et al. 1981) have always involved free amino acid mixtures in the culture medium. Our results show that extra amino acids in the form of hydrolysed casein can act as an effective source of nutritional protein for isolated cells. Indeed, increased protein levels modified lipogenic activities suggesting the incorporation of this protein into the main metabolic routes of the hepatocytes. Given the increase in ACL and G6PD activity and decrease in FAS activity, hydrolysed casein was certainly used as a source of energy, with its glucogenic amino acids transformed into glucose through intermediates of the citric-acid cycle. This finding is comparable with those of earlier studies on the use of free amino acids by trout hepatocytes which are mainly catabolised to provided energy (French et al. 1981) and with in vivo studies on eel and carp also showing increased liver amino acid catabolism with increased dietary protein levels (Suarez et al. 1995; Shimeno et al. 1995).

In the organism, fatty acids are not only used as an energy source and as structural components of biological membranes, but are also important mediators of gene expression (Simopoulos, 1996). In rat hepatocytes, polyunsaturated fatty acids inhibit the expression of lipogenic enzymes (Stabile et al. 1998). This is consistent with the inhibition by dietary polyunsaturated fat of lipogenesis observed in the liver (Zampelas et al. 1995) and also consistent with the present general inhibitory effect of linolenic, eicosapentaenoic and docosahexaenoic (n-3) fatty acids on lipogenic activity. The inhibition of lipogenic enzyme activities by PUFA takes place in three stages. As reflected here, PUFA directly inhibit FAS by a specific mechanism which causes a lower cytoplasmic consumption of malonyl-CoA and NADPH (Clarke \& Jump, 1994; Hillgartner et al. 1995). The accumulation of the latter leads to the practically concurrent inhibition of G6PD and ACoAC. Finally, the simultaneous slight inhibitory effect of high PUFA levels on ACL and ME activity seen here may reflect late inhibition by the accumulation of their products. In our experiment, some of the supplemented PUFA seemed to be used for energy production as previously described (Henderson, 1996) although some degree of direct incorporation into lipids has also been reported for fish hepatocytes (Sellner \& Hazel, 1982). Effectively, the level of dietary fish oil has been shown to alter susceptibility to lipid peroxidation by modification of metabolic behaviour in rainbow trout and sea bass (Alvarez et al. 1998).

The analysis of the lipogenic effects of each macronutrient (glucose, protein and fatty acids) in the trout hepatocytes was aimed at providing preliminary information prior to exploring the overall effects of changes in the ratios of these macronutrients (Tables 1 and 4). In general, the metabolic potentials of different dietary treatments have been explored by means of long-term in vivo experiments (Gandemer et al. 1983; Bols \& Lee, 1991; Alvarez et al. 1998) and there is a lack of information on the modulation of metabolic capacity by gross macronutrient variation in the cell culture medium. Most of the effects of the individual macronutrients on lipogenic activity observed here were comparable with those recorded when their relative proportions to the other macronutrients were modified. Nevertheless, certain differ- 
ences became apparent. For instance, at some high fatty acid concentrations (Table 4, media 4 and 8) there was notable inhibition of ME activity by increased glucose concentration (medium 4). This was contrary to the effect observed when the activity of this enzyme was assayed independently in the presence of fatty acids and glucose (Table 3 and Fig. 1). The activities of ACL, FAS and ACoAC were also modulated by changes in the proportions of one or more of the macronutrient. The modulation capacity of these enzyme activities by individual intermediates of energetic metabolism has been described in fish (for review see Segner \& Böhm, 1994) and, from the results here shown, it is apparent that substantial changes in the lipogenic pathways can be produced by interacting amounts of nutritional substrates (glucose-amino acidsfatty acids) made available to the fish hepatocytes at a given time. Thus, in our cultures, increased amounts of fatty acids in the medium greatly diminished lipogenic activities, although these were quantitatively different depending on the amount of energy provided by glucose and amino acids, mimicking the nutritional regulation observed in vivo (Likimani \& Wilson, 1982; Iritani et al. 1984). Moreover, a glucose or protein C source seems to be equally efficient for lipogenesis since a high amount of either substrate guaranteed high lipogenic activities and this effect was additive when elevated amounts of both substrates were included (e.g. Table 4, medium 3). The low-glucose or low-protein media showed the least capacity for inducing lipogenic activity. This physiological explanation in terms of nutritional regulation is in accordance with the observation that hepatic lipid accumulation in re-fed carps is enhanced by excess energy transformed into biosynthetic power in the form of NADPH (Böhm et al. 1994). This implies that de novo lipogenesis is concomitantly favoured by media containing a high amount of energy in the form of glucose and protein and a low amount of fatty acids.

The general findings of the present investigation are in agreement with those of in vivo fish studies which report the stimulation of lipogenesis by high-carbohydrate diets (Likimani \& Wilson, 1982; Dias et al. 1998) and inhibition by dietary fat (Shimeno et al. 1996). Moreover, in the present cultures, the inhibitory effect of high-protein diets on fish lipogenesis (Shikata et al. 1993) was also observed at the highest fatty acid level in accordance with the in vivo interactive effects of dietary protein and fat observed in rainbow trout and sea bass liver lipogenesis (Alvarez et al. 1998; Dias et al. 1998).

Our findings demonstrate the feasibility of investigating the direct regulation of lipogenesis in isolated fish cells by mimicking in vivo dietary conditions and changing the relative proportions of the main macronutrients. It is conceivable that this approach could be extrapolated to the investigation of the macronutrient regulation of other metabolic routes.

\section{Acknowledgements}

This investigation was financed by a European Commission project (AIR2-CT93-0801) and a Spanish CICYT grant (AGF95-1341). The authors thank S. Pérez-Benavente for her excellent technical assistance. We are particularly indebted to S. J. Kaushik and G. Corraze for suggestions, helpful discussion and the generous provision of trout serum.

\section{References}

Alvarez MJ, López-Bote CJ, Diez A, Corraze G, Arzel J, Dias J, Kaushik SJ \& Bautista JM (1998) Dietary fish oil and digestible protein modify susceptibility to lipid peroxidation in the muscle of rainbow trout (Oncorhynchus mykiss) and sea bass (Dicentrarchus labrax). British Journal of Nutrition 80, 281289.

Ashida H, Nakai R, Kanazawa K \& Danno G (1998) Xenobiotic tolerance of primary cultured hepatocytes in rats fed a high-fat or high-protein diet. Journal of Nutritional Science and Vitaminology 44, 89-102.

Bautista JM, Garrido-Pertierra A \& Soler G (1988) Glucose-6phosphate dehydrogenase from Dicentrarchus labrax liver: kinetic mechanism and kinetics of NADPH inhibition. Biochimica et Biophysica Acta 967, 354-363.

Bell MV, Henderson JR \& Sargent JR (1986) The role of polyunsaturated fatty acids in fish. Comparative Biochemistry and Physiology 83B, 711-719.

Bergot F (1979) Effects of dietary carbohydrates and of their mode of distribution on glycaemia in rainbow trout (Salmo gairdneri R.). Comparative Biochemistry and Physiology 64A, 543-547.

Böhm R, Hanke W \& Segner H (1994) The sequential restoration of plasma metabolite levels, liver composition and liver structure in refed carp, Cyprinus carpio. Journal of Comparative Physiology 164B, 32-41.

Bols NC \& Lee LEJ (1991) Technology and uses of cell cultures from tissues and organs of bony fish. Cytotechnology 6, 163187.

Brauge C, Medale F \& Corraze G (1994) Effect of diet carbohydrate levels on growth, body composition and glycaemia in rainbow trout, Oncorhynchus mykiss, reared in seawater. Aquaculture 123, 109-120.

Chen RF (1967) Removal of fatty acids from serum albumin by charcoal treatment. Journal of Biological Chemistry 242, 173181.

Clarke SD \& Jump DB (1994) Dietary polyunsaturated fatty acid regulation of gene transcription. Annual Review of Nutrition 14, 83-98.

Dias J, Alvarez MJ, Diez A, Arzel J, Corraze G, Bautista JM \& Kaushik SJ (1998) Regulation of hepatic lipogenesis by dietary protein/energy in juvenile European sea bass (Dicentrarchus labrax). Aquaculture 161, 169-186.

Foufelle F, Girard J \& Ferre P (1996) Regulation of lipogenic enzyme expression by glucose in liver and adipose tissue: a review of the potential cellular and molecular mechanisms. Advances in Enzyme Regulation 36, 199-226.

French CJ, Mommsen TP \& Hochachka PW (1981) Amino acid utilisation in isolated hepatocytes from rainbow trout. European Journal of Biochemistry 113, 311-317.

Fynn-Aikins K, Hung SSO, Liu W \& Li H (1992) Growth, lipogenesis and liver composition of juvenile white sturgeon fed different levels of D-glucose. Aquaculture 105, 61-72.

Gandemer G, Durand G \& Pascal G (1983) Relative contributions of the main tissues and organs to body fatty acid synthesis in the rat. Lipids 18, 223-228.

Geelen MJH (1994) Medium-chain fatty acids as short-term regulators of hepatic lipogenesis. Biochemical Journal 302, $141-146$.

Gongnet GP, Meyerburgdorff KH, Becker K \& Gunther KD (1996) Influence of various protein sources on protein digestion 
and metabolism of growing mirror carp (Cyprinus carpio, L). Revue de Medecine Veterinaire 147, 63-68.

Harmon JS \& Sheridan MA (1992a) Glucose-stimulated lipolysis in rainbow trout Oncorhynchus mykiss, liver. Fish Physiology and Biochemistry 10, 189-199.

Harmon JS \& Sheridan MA (1992b) Effects of nutritional state, insulin and glucagon on lipid mobilization in rainbow trout, Oncorhynchus mykiss. General and Comparative Endocrinology 87, 214-221.

Henderson RJ (1996) Fatty acid metabolism in freshwater fish with particular reference to polyunsaturated fatty acids. Archives of Animal Nutrition - Archiv fur Tierernahrung 49, 5-22.

Henderson RJ \& Tocher DR (1987) The lipid composition and biochemistry of freshwater fish. In Progress in Lipid Research, pp. 281-347 [RT Holman, WW Christie and H Sprecher, editors]. New York, NY: Pergamon Press.

Hillgartner FB, Salati LM \& Goodridge AG (1995) Physiological and molecular mechanisms involved in nutritional regulation of fatty acid synthesis. Physiological Reviews 75, 47-76.

Hilton JW \& Atkinson JL (1982) Response of rainbow trout (Salmo gairdneri) to increased levels of available carbohydrate in practical trout diets. British Journal of Nutrition 47, 597607.

Holland R, Witters LA \& Hardie DG (1984) Glucagon inhibits fatty acid synthesis in isolated hepatocytes via phosphorylation of acetyl-CoA carboxylase by cyclic AMP-dependent protein kinase. European Journal of Biochemistry 140, 325-333.

Hsu RY, Butterworth PHW \& Porter JW (1969) Pigeon liver fatty acid synthetase. In Methods in Enzymology, vol. 14, pp. 33-39 [JM Lowenstein, editors]. New York, NY: Academic Press Inc.

Hung SSO \& Storebakken T (1994) Carbohydrate utilisation by rainbow trout is affected by feeding strategy. Journal of Nutrition 124, 223-230.

Iritani N, Ikeda Y, Fukuda H \& Katsurada A (1984) Comparative study of lipogenic enzymes in several vertebrates. Lipids $\mathbf{1 9}$, $828-835$.

Klauning JE (1984) Establishment of fish hepatocyte cultures for use in in vitro carcinogenicity studies. National Cancer Institute Monographs 65, 163-173.

Klauning JE, Ruch RJ \& Goldblatt PJ (1985) Trout hepatocyte culture: isolation and primary culture. In Vitro Cellular and Developmental Biology 21, 221-228.

Leger C, Fremont L \& Boudon M (1981) Fatty acid composition of lipids in the trout. Influence of dietary fatty acids on the triglyceride fatty acid desaturation in serum, adipose tissue, liver, white and red muscle. Comparative Biochemistry and Physiology 69B, 99-105.

Leibovitz A (1963) The growth and maintenance of tissue cell cultures in free gas exchange with the atmosphere. American Journal of Hygiene 78, 173-180.

Likimani TA \& Wilson RP (1982) Effects of diet on lipogenic enzyme activities in channel catfish hepatic and adipose tissue. Journal of Nutrition 112, 112-117.

Lin H, Romsos DR, Tack PI \& Leveille GAJ (1977) Influence of diet on in vitro and in vivo rates of fatty acid synthesis in coho salmon. Journal of Nutrition 107, 1677-1682.

Moon TW, Walsh PJ \& Mommsen TP (1985) Fish hepatocytes. A model metabolic system. Canadian Journal of Fisheries and Aquatic Sciences 42, 1772-1782.

Newsholme EA \& Start C (1973) Regulation of carbohydrate metabolism in liver and regulation of fat metabolism in liver. In Regulation in Metabolism, chapters 6 and 7, pp. 247-316 [EA Newsholme and C Start, editors]. New York, NY: John Wiley \& Sons.

Ochoa S (1955) Malic enzyme. In Methods in Enzymology, vol. 1, pp. 739-753 [SP Colowicks and NO Kaplan, editors]. New York, NY: Academic Press Inc.

Officer DI, Batterham ES \& Farrel DJ (1997) Comparison of growth performance and nutrient retention of weaner pigs given diets based on casein, free amino acids or conventional proteins. British Journal of Nutrition 77, 731-744.

Pereira C, Vijayan MM \& Moon TW (1995) In-vitro hepatocyte metabolism of alanine and glucose and the response to insulin in fed and fasted rainbow trout. Journal of Experimental Zoology 271, 425-431.

Segner H (1998) Isolation and primary culture of teleost hepatocytes. Comparative Biochemistry and Physiology 120A, 71-81.

Segner H, Blair JB, Wirtz G \& Miller MR (1994) Cultured trout liver cells: utilisation of substrates and response to hormones. In Vitro Cellular and Developmental Biology 30A, 306-311.

Segner H \& Böhm R (1994) Enzymes of lipogenesis. In Biochemistry and Molecular Biology of Fishes, vol. 3, pp. 313-325 [PW Hochachka and TP Mommsen, editors]. Amsterdam: Elsevier.

Sellner PA \& Hazel JR (1982) Incorporation of polyunsaturated fatty acids into lipids of rainbow trout hepatocytes. American Journal of Physiology 243, R223-R228.

Sheridan MA (1994) Regulation of lipid metabolism in poikilothermic vertebrates. Comparative Biochemistry and Physiology 107B, 495-508.

Shikata T, Masumoto T \& Shimeno S (1993) Metabolic response to restricted feeding of a high protein diet in common carp. Nippon Suisan Gakkaishi 59, 1587-1591.

Shimeno S, Hosokawa H \& Takeda M (1996) Metabolic response of juvenile yellowtail to dietary carbohydrate to lipid ratios. Fisheries Science 62, 945-949.

Shimeno S, Kheyyali D \& Shikata T (1995) Metabolic response to dietary lipid to protein ratios in common carp. Fisheries Science 61, 977-980.

Simopoulos AP (1996) The role of fatty acids in gene expression: health implications. Annuals of Nutrition and Metabolism 40, 303-311.

Spector AA, Mathur SN, Kaduce TL \& Hyman BT (1981) Lipid nutrition and metabolism of cultured mammalian cells. Progress of Lipid Research 19, 155-186.

Srere PA (1962) Citrate cleavage enzyme. In Methods in Enzymology, vol. 5, pp. 641-644 [SP Colowicks and NO Kaplan, editors]. New York, NY: Academic Press Inc.

Stabile LP, Klautky SA, Minor SM \& Salati LM (1998) Polyunsaturated fatty acids inhibit the expression of the glucose-6-phosphate dehydrogenase gene in primary rat hepatocytes by a nuclear posttranscriptional mechanism. Journal of Lipid Research 39, 1951-1963.

Suarez MD, Hidalgo MC, García Gallego M, Sanz A \& De la Higuera M (1995) Influence of the relative proportions of energy yielding nutrients on liver intermediary metabolism of the European eel. Comparative Biochemistry and Physiology 111A, 421-428.

Tocher DR, Carr J \& Sargent JR (1989) Polyunsaturated fatty acid metabolism in fish cells: differential metabolism of $n-3$ and $n-6$ series acids by cultured cells originating from a freshwater teleost fish and from a marine teleost fish. Comparative Biochemistry and Physiology 94B, 367-374.

Tocher DR, Sargent JR \& Frerichs GN (1988) The fatty acid compositions of established fish cell lines after long term culture in mammalian sera. Fish Physiology and Biochemistry 5, 219-227.

Voss B \& Jankowsky HD (1986) Temperature-dependence of lipogenesis in isolated hepatocytes from rainbow trout (Salmo gairdneri). Comparative Biochemistry and Physiology B Biochemistry and Molecular Biology 83, 13-22. 
Wilson MD, Blake WL, Salati LM \& Clarke SD (1990) Potency of polyunsaturated and saturated fats as short term inhibitors of hepatic lipogenesis in rats. Journal of Nutrition 120, 544-552.

Wilson RP (1994) Review: utilisation of dietary carbohydrate by fish. Aquaculture 124, 67-80.
Zampelas A, Morgan LM, Furlonger N \& Williams CM (1995) Effects of dietary fatty acid composition on basal and hormonestimulated hepatic lipogenesis and on circulating lipids in the rat. British Journal of Nutrition 74, 381-392. 